\title{
An Influence of Certain Psycho-Sociological Factors on Teacher Effectiveness of Primary School Teachers
}

\author{
Dr. Y. Madhusudhana Reddy \\ Principal, Global Institute of Advance Study in Education, Gangavaram, Palamaner, Chittoor(District), Andhra Pradesh, India
}

\begin{abstract}
An Influence of certain psycho-sociological factors on Teacher Effectiveness among Primary School Teachers of Chittoor District, A.P.” was undertaken. $i$. To assess the general level of Teacher Effectiveness of Primary School Teachers. ii. To find the relation between different independent, personal, demographic and personality variables and teacher effectiveness of Primary School Teachers. Since this problem envisages the investigation of the Teacher effectiveness of the primary school teachers in relation to the variables such as attitude towards teaching, job satisfaction, job involvement, home environment, personality characteristics and some personal-demographic variables viz., gender, locality, management, experience, age, qualifications, size of the family, etc., The statistical treatment of the data reveals the following major findings of the study. A. Frequency Distribution i. The mean teacher effectiveness score of the primary school teachers is 432.35 where the neutral point of the scale is 300.00 . Hence, the teacher effectiveness of the primary school teachers is above average. The values of mean, median and mode of the distribution is $432.35,447.00$ and 450.00 respectively. There is a gap among these three values. Therefore, the distribution is following the normal distribution with slight difference. ii. The values of Skewness and Kirtosis of the attitude scores of the teachers are - 1.031 and 0.570 respectively. Hence, the distribution of the teacher effectiveness scores for the whole group of teachers is slightly negatively skewed and Lepto Kurtic.
\end{abstract}

Keywords: certain psycho-sociological factors on Teacher Effectiveness among Primary School Teachers

\section{Introduction}

A profession is a calling and it implies acquisition of a fund of knowledge, range of skills and their application in the service of humanity.

A profession is explained as an occupation based upon specialized, intellectual study and training. It is a work pursuit, one person's effort to find out a place in the work-aday world. It is a kind of occupation, in which bygone times termed as "Vocation", a calling.

The teaching profession occupies a position of public trust involving not only the individual teacher's personal conduct but also the interaction of the school and the community. He should perform the duties of citizens and participate in community activities. He has to discuss controversial issues from an object point of view keeping the class from partisan opinions.

The teaching profession should be intellectual, learning and practical activity. A strong, secure and effective profession of teaching is essential to build up public intelligence and to solve the social problems. Teachers who commit themselves to the profession and who have knowledge, devotion and sacrifice can only build teaching profession.

The role of the teacher in a society is well known. The wellbeing of the Nation depends upon the well being of the teachers. The teacher has a powerful and abiding influence in the formation of the character of the future citizens. The teacher acts as a pivot for the transmission of intellectual and technical skills and cultural traditions from one generation to another.

\section{Teacher Effectiveness}

Effective teaching means teaching which produces maximum learning outcome. It aims to achieve the goals of education. It may be stated that 'pupil' is the most relevant criterion for teacher effectiveness. Educationists, administrators and psychologists know well about the importance of effective teaching. The effectiveness could be achieved with the help of skilfull and efficient teachers, well planned syllabus, necessary infrastructural facilities, etc.

Teacher effectiveness is associated with a seemingly endless series of tasks. The teacher is ever involved in planning learning experiences for children, choosing instructional materials, gathering supplies, instructing, evaluating work, correcting written work, collecting money and goods for one purpose or another, having parent conference and participating in staff meetings and professional associations.

The teacher effectiveness is also called effective teaching, criteria for competence and ability to teach and teaching success. The effective teaching is essential concerned with how best to bring about the desired pupil learning by some educational activity. Over the years thinking about effective teaching can be approached in different ways.

One of the most difficult problems in educational research is that of recognizing teacher effectiveness and discrimination between the more and less effective teachers. The impact of any educational programme or innovation on the pupil operates through the pupil's teacher. It is, therefore, quite accurate to say that school's effectiveness depends directly on the effectiveness of its teachers. Maximizing the teacher effectiveness is a major goal of education. 


\section{Statement of the Problem}

The present investigation entitled- "An Influence of certain psycho-sociological factors on Teacher Effectiveness among Primary School Teachers of Chittoor District, A.P." was undertaken.

\section{Review of Related Literature}

Vijaya Lakshmi (2005) conducted a study on 'teacher effectiveness and job satisfaction of women teachers'. This study was carried out with the main objective of the relationship between teacher effectiveness and job satisfaction. Besides these, the effect of locality, management and subject of teaching on teacher effectiveness and job satisfaction were also studied. The findings showed low and positive correlation between teacher effectiveness and job satisfaction. Only the management of school has significant impact on both teacher effectiveness and job satisfaction. The other variables included in the study viz., locality and subject of teaching have no significant impact on bother teacher effectiveness and job satisfaction among the women teachers.

Arockia Doss (2007) conducted a study on 'Teacher Effectiveness of College Teachers'. Findings of the study were - (i) majority of college teachers are effective only at moderate level, (ii) Personal factors viz., age, sex, subject of teaching, designation, academic qualification, management of the institution, nature of institution, locality and courses offered, have significant influence on various dimensions of teacher effectiveness.

Sharadha and Paremeswaram (2008) in their study on 'Teacher characteristics and Learning in the classroom' make an attempt to examine the role of some behavioural variations among teachers and their possible implications for effective classroom teaching and learning. The findings were - gender, locality and management of the institutions had significant impact on the behaviour variations in the level of their teaching effectiveness.

Sundara Rao (2009) investigated teacher effectiveness as an observational study by using 90 teaching staff through the observational techniques. He found that sex had no significant affiliation with teacher effectiveness scores. However, in the case of patience and sympathy, women teachers are better than men teachers. In all other aspects men teachers were better than women teachers. Language and Humanities teachers were less friendly, Science teachers were stereotyped and humanities teachers were more communicative. A positive and strong association was found between teacher effectiveness and attainment of the B.Ed level.

Haslett (2010) studied on the dimensions of teacher effectiveness. It was found that a student/teacher rapport was characterized by the qualities of trust worthiness, fairness, cooperativeness and openness are accounted for $54 \%$ of the variance explained by these factors.
Adval (2010) conducted an experimental investigation on 'teacher effectiveness'. The investigator examines the nature of teacher effectiveness in relation to teaching aptitude, teaching ability and interest. The conclusions are that the teacher effectiveness is highly correlated with the teaching aptitude, teaching ability and interest in teaching. It also concluded that as these variables are in increasing position, the level of teacher effectiveness also found increased.

Hunka and Anderson (2011) spot light problem areas in research on teacher effectiveness. They discuss studies which have used predictor or criterion variables and conclude that this research has reached a dead end. Attempts to build a theory of teaching from a statistical description of what is happening fail to prescribe what should be happening, even examples of the best of teaching may not provide the theoretical basis for the most effective teaching.

\section{Need for the Study}

There is a pressing need of objectivity to assess the work of the teacher. Basically, some criteria should be specified in order to identify the teachers of high caliber. Quality improvement of teaching profession should be accorded the top most priority. The first and the foremost need is to conduct multidimensional research in this field. Likewise, if definite predictors of teacher effectiveness are known preciously, it may be possible to help school administrators in their attempt to promote quality in education.

Teaching Effectiveness continues to be the most important variable held in high esteem, in all cultures, countries and times. Hence the research related to the area of teaching effectiveness is an ever growing concern of the researchers, educationists and administrators. Any enquiry into the previous works suggested that studies related to this area may be broadly classified into two major categories viz., (i) Studies related to Psychological base and (ii) Studies related to Sociological base.

The efficiency of a professional like a doctor, an engineer or a lawyer can be easily evaluated on the basis of the results of their performance (the productive criterion). The apparent product of teaching is the examination results of the students. Since the examination system is defective, we are not justified in basing upon the marks or grades as the criterion of the effectiveness of the teaching. Teaching cannot be just a set of skills. It is much more than that. That is why the term 'teacher training' has been replaced by the comprehensive term 'teacher education'. Educating the 'would be teacher' (prospective teacher) means giving the necessary knowledge, skills, attitudes, etc., through an academic programme involving both theoretical instruction and practice teaching.

The famous study of characteristics of teachers by Ryans (1960) is a classical example of criterion approach of research on teaching. In a number of studies, teaching effectiveness is sought by means of multiple regression analysis involving the use of variables such as personality traits and environmental factors. In a study Lomax (1972) quoted - 'Although we have seen more than half a century research in the field of teacher training, no standards yet 


\section{International Journal of Science and Research (IJSR) \\ ISSN (Online): 2319-7064}

Index Copernicus Value (2015): 78.96 | Impact Factor (2015): 6.391

exist which are generally agreed to be the criterion of teaching success'. He declared that the task of identifying effective teaching was crucial to teacher education, certification, selection and promotion.

The early researches on teaching effectiveness tended to focus on the relationship between presage variables and product variables, so called 'black box research'. The search for effectiveness in teaching has been a focal point in educational research for decades. There is no comprehensive theory of teaching of and no generally accepted criteria for evaluating teaching effectiveness in general.

In this background there is a great need for improving the standards in the schools. Therefore, for the present study 'Teaching Effectiveness in relation to certain psychosociological factors' was selected. Teacher effectiveness, thus, is being multi-dimensional. It can be determined with the help of personality characteristics and some other demographic variables. It may also depend upon personal variables and institutional and situational factors.

Thus, the present study 'Influence of certain psychosociological factors on the teaching effectiveness of primary school teachers" is designed to analyze the level of Teaching Effectiveness of the Primary School Teachers in relation to different variables like Attitude towards teaching, job satisfaction, Job Involvement and Home Environment along with Personality Characteristics and some personal and demographic variables (gender, age, experience, management, educational qualifications, marital status etc.)

\section{Objectives of the Study}

The major objectives of the present study are:

1) To assess the general level of Teacher Effectiveness of Primary School Teachers.

2) To find the relation between different independent, personal, demographic and personality variables and teacher effectiveness of Primary School Teachers.

3) To find out the influence of Independent variables (Attitude towards teaching, Job Satisfaction, Job Involvement and Home Environment) of the Primary school teachers on their level of Teacher Effectiveness.

4) To find out the influence of personal-demographic variables on teacher effectiveness of Primary School Teachers.

5) To identify the influence of Personality factors on the Teacher Effectiveness of Primary School Teachers.

6) To make a comparative study of the personality profiles of the Effective and Ineffective Primary School Teachers.

7) To determine the degree of association between the scores of teacher effectiveness with different independent variables.

8) To develop multiple regression equations to predict Teacher Effectiveness of the Primary School Teachers.

\section{Hypotheses}

In the light of the above objectives, the following Null hypotheses have been set up for the purpose of this investigation.
1) The Primary School Teachers, in general, would not have high level of Teaching Effectiveness in their profession.

2) There is no relationship between independent variables and teacher effectiveness of primary school teachers.

a) There is no relationship between attitude towards teaching and teacher effectiveness of primary school teachers.

b) There is no relationship between job satisfaction and teacher effectiveness of primary school teachers.

c) There is no relationship between job involvement and teacher effectiveness of primary school teachers.

d) There is no relationship between home environment and teacher effectiveness of primary school teachers.

e) There is no relationship between personal and demographic variables and teacher effectiveness of primary school teachers.

f) There is no relationship between personality factors and teacher effectiveness of primary school teachers.

3) Independent variables would not have any significant influence on the Teacher Effectiveness of Primary School Teachers.

a) Attitude towards Teaching of Primary School Teachers would not have significant influence on their Teacher Effectiveness.

b) Job Satisfaction of Primary School Teachers would not have significant influence on their level of Teacher Effectiveness.

c) Job Involvement would not have any significant influence on the teacher effectiveness of Primary School Teachers.

d) Home Environment of Primary School Teachers would not have significant influence on their level of Teacher Effectiveness.

4) Personal-demographic variables would not influence the level of Teacher Effectiveness of Primary School Teachers.

a) Gender would not influence the level of Teacher Effectiveness of the Primary School Teachers.

b) Age would not influence the level of Teacher Effectiveness of the Primary School Teachers.

c) Experience would not influence the level of Teacher Effectiveness of the Primary School Teachers.

d) Educational Qualification would not influence the level of Teacher Effectiveness of the Primary School Teachers.

e) Locality would not influence the level of Teacher Effectiveness of the Primary School Teachers.

f) Type of Management would not influence the level of Teacher Effectiveness of the Primary School Teachers.

g) Type of school would not influence the level of Teacher Effectiveness of the Primary School Teachers.

h) Caste would not influence the level of Teacher Effectiveness of the Primary School Teachers.

i) Religion would not influence the level of Teacher Effectiveness of the Primary School Teachers.

j) Marital Status would not influence the level of Teacher Effectiveness of the Primary School Teachers. 


\section{International Journal of Science and Research (IJSR) \\ ISSN (Online): 2319-7064}

Index Copernicus Value (2015): 78.96 | Impact Factor (2015): 6.391

k) Type of the Family would not influence the level of Teacher Effectiveness of the Primary School Teachers.

1) Size of the Family would not influence the level of Teacher Effectiveness of the Primary School Teachers

5) Personality factors of the Primary School Teachers would not have significant bearing on their Teacher Effectiveness.

6) There would be no significant difference between the Personality profiles of Primary School Teachers with high and low levels of Teacher Effectiveness.

7) There would be no significant association between the different independent, personal and demographic variables of the primary school teachers and their level of teacher effectiveness

8) It would not be possible to develop the regression equations to predict Teacher Effectiveness of Primary School Teachers with the help of independent variables of the present investigation.

\section{Variables Included}

Since this problem envisages the investigation of the Teacher effectiveness of the primary school teachers in relation to the variables such as attitude towards teaching, job satisfaction, job involvement, home environment, personality characteristics and some personal-demographic variables viz., gender, locality, management, experience, age, qualifications, size of the family, etc., a brief description of the variables employed in the study is presented below.

\section{1) Dependent variables}

The dependent variables included in this study is : $\underline{\text { Teacher }}$ Effectiveness

\section{2) Independent variables}

The independent variables are broadly grouped under three categories as given below:
A. Psycho-sociological variables
a) Attitude towards Teaching
b) Job Satisfaction
c) Job Involvement
d) Home Environment

\section{B. Personality Characteristics}

C. Personal - demographic variables

a) Gender

b) Age

c) Experience

d) Qualification

e) Locality

f) Management

g) Type of school

h) Caste

i) Religion

j) Marital Status

k) Type of family

1) Size of family

\section{Methods of Investigation}

\section{1) Research Tools}

The following tools are used for the present investigation.

- Teacher Effectiveness Scale - developed and standardized by Dr UMME KULSUM (2009) - adopted.

- Attitude towards Teaching Scale - developed and standardized by Dr. UMME KULSUM (2008) - adopted.

- Job Satisfaction Scale - developed and standardized by KUNUNGO (1982) - adopted.

- Job Involvement Inventory - developed and standardized by Dr. Vidhya Latha (2006) - adopted.

- Home Environment Scale - developed and standardized by KAILASA LINGAM (1994) - adopted.

- 16 Personality Factors Inventory - R.B. Cattell (16PF form-B) - adopted.

- Personal data sheet developed for the purpose.

\section{2) Scoring}

- As per the norms developed for tests scoring is given for Teacher Effectiveness and Attitude towards teaching scale.

- As per the norms given in the manual of Job Satisfaction scale and Job Involvement Inventory.

- As per the manual scoring given for the Home Environment Inventory.

- As per the manual scoring is given for personality factors scale (form-c).

- The information furnished by the primary school teachers on demographic and other variables was numerically coded in order to suit the computer analysis.

\section{3) Sample}

The problem is aimed at measuring teacher effectiveness of Primary School Teachers working in different Elementary School of Chittoor District of Andhra Pradesh. Therefore, the population of the study constitutes all those who teach to the primary grades (Class I to V) in the Primary and Upper Primary schools.

At the first stage the list of Primary and Upper primary schools in the Chittoor District was obtained from the Office of the District Educational Officer. The total number of schools was divided into three groups basing on their management viz., Government, Municipality and Private Schools. From each stratum a representative sample of schools were selected at random. The total number of schools thus selected was 330 .

In the second stage all the primary school teachers were categorized as men and women teachers by adopting cluster sampling technique. Thus, a total sample of 750 primary school teachers working in 330 elementary schools was selected by two-stage stratified random sampling technique. The gist of the sampling is given here under a table form.

Sample Frame

\begin{tabular}{|c|c|c|c|c|c|c|c|}
\hline $\begin{array}{c}\text { Management } \\
\text { Schools }\end{array}$ & \multicolumn{2}{|c|}{$\begin{array}{c}\text { Government } \\
(150)\end{array}$} & \multicolumn{2}{|c|}{$\begin{array}{c}\text { Municipality } \\
(90)\end{array}$} & \multicolumn{2}{|c|}{$\begin{array}{c}\text { Private } \\
(90)\end{array}$} & $\begin{array}{c}\text { Total } \\
(330)\end{array}$ \\
\hline Gender & Men & Women & Men & Women & Men & Women & \\
\hline Sample & 125 & 125 & 125 & 125 & 125 & 125 & 750 \\
\hline
\end{tabular}




\section{International Journal of Science and Research (IJSR) \\ ISSN (Online): 2319-7064}

Index Copernicus Value (2015): 78.96 | Impact Factor (2015): 6.391

\section{4) Method}

A suitable method helps the investigator to explore the diverse stands of the study and adequately measure them so as to satisfy the requirements and thus it is the means to an end. The present study concerns itself with an exploration and description of teacher effectiveness and personality characteristics of primary school teachers. Hence, the present study is a survey type investigation.

\section{5) Collection of data}

As explained earlier, data from the primary school teachers is collected. The number of school thus selected from the Chittoor District is 330 Elementary Schools (both Primary and Upper Primary). A good rapport was developed with the teachers and they were explained the purpose and importance of the study as a matter of motivation.

The primary school teachers were given a copy of all the instruments viz., Teacher Effectiveness Scale, Attitude towards Teaching Profession Scale, Job Satisfaction Scale, Job Involvement Inventory, Home Environment scale, 16 Personality Factors questionnaire and personal data sheet and requested them to respond to all parts of the booklet of instruments and to all items without leaving any part or any item. Though all the above instruments were selfexplanatory, they were explained clearly to each of them. Sufficient time was given to them to respond the items.

\section{6) Analysis}

The total scores obtained by each of 720 Elementary Schools Teachers on all the variables were computed. The data was analysed using relevant statistical techniques like ' $\mathrm{t}$ ' test, ANOVA, Chi-square test, etc., to find out whether the differences in the independent variables accounted for significant differences in the dependent variables i.e. job satisfaction and teacher effectiveness. The usual levels of significance, viz., 0.05 and 0.01 levels, were employed to test the significance of the obtained values.

Further, step wise multiple regression analysis was applied to find out whether it is possible to predict the two dependent variables viz., Job Satisfaction and Teaching Effectiveness with the help of the independent variables viz., self-concept, Job Involvement, Home Environment, Personality factors and the demographic variables viz., management, gender, experience, age, qualification, locality, etc.

The profile similarity coefficient ' $r$ ' was computed to test whether there was any significant dissimilarity between the profiles of the teacher educators who were satisfied and dissatisfied in their profession and also between the teacher educators who are highly effective and ineffective in their job.

The obtained numerical results were also adumbrated by graphical representation wherever necessary.

\section{Findings of the Study}

The statistical treatment of the data reveals the following major findings of the study.

\section{A. Frequency Distribution}

1) The mean teacher effectiveness score of the primary school teachers is 432.35 where the neutral point of the scale is 300.00 . Hence, the teacher effectiveness of the primary school teachers is above average. The values of mean, median and mode of the distribution is 432.35 , 447.00 and 450.00 respectively. There is a gap among these three values. Therefore, the distribution is following the normal distribution with slight difference.

2) The values of Skewness and Kirtosis of the attitude scores of the teachers are -1.031 and 0.570 respectively. Hence, the distribution of the teacher effectiveness scores for the whole group of teachers is slightly negatively skewed and Lepto Kurtic.

\section{B. Simple Correlation}

1) Attitude towards teaching, job satisfaction and job involvement of the primary school teachers has significant positive correlation with their overall teacher effectiveness where as the home environment possessed significant negative correlation.

2) The teacher effectiveness of the primary school teachers has a significant correlation with the demographic variables viz., Gender, Age, Experience, Locality, Management and Type of school.

3) None of the 16 personality factors showed a significant correlation with the teacher effectiveness among the primary school teachers.

\section{Critical Ratios}

1) Primary School Teachers with high attitude towards teaching showed higher teacher effectiveness compared to the teachers with less and average attitude towards teaching profession.

2) The dimensions of attitude towards teaching - academic issues, administrative matters, socio-psychological problems, co-curricular activities and economic aspects had shown significant influence on the overall teacher effectiveness of the primary school teachers. The teachers who had less scores on these dimensions exhibited lower teacher effectiveness and the high scorers, higher teacher effectiveness.

3) Similarly the teachers with less job satisfaction expressed poor level of teacher effectiveness compared to the teachers with average and high level of job satisfaction.

4) It was also found that the teachers with poor home environment exhibited higher level of teacher effectiveness compared to the teachers with moderate and good level of home environment.

5) Women teachers exhibited higher level of teacher effectiveness compared to the men teachers.

6) The young and old aged teachers expressed higher level of teacher effectiveness compared to the middle aged teachers.

7) High experienced teachers had higher level of teacher effectiveness compared to the less and average experience.

8) Suitable qualified teachers had higher level of teacher effectiveness compared to the teachers with higher / extra qualifications.

9) Urban area teachers possessed higher level of teacher effectiveness compared to the rural area teachers. 


\section{International Journal of Science and Research (IJSR) \\ ISSN (Online): 2319-7064 \\ Index Copernicus Value (2015): 78.96 | Impact Factor (2015): 6.391}

10)Private school teachers had higher level of teacher effectiveness compared to the government and private school teachers.

11)Teachers working in Upper primary schools had higher level of teacher effectiveness compared to the teachers working in Primary schools.

12)Teachers having medium sized family exhibited higher level of teacher effectiveness than the teachers with small and big sized families.

13)The teachers with the personality qualities $C, G$ and $Q_{3}$ differ significantly in their level of teacher effectiveness among the 16 personality characteristics.

\section{Chi - square analysis}

1) Independent variables viz., attitude towards teaching, job satisfaction, home environment have significant association among the primary school teachers with the less, average and high teacher effectiveness.

2) The personal-demographic variables - gender, age, experience, locality, management of the school, type of school and size of the family have significant association among the primary school teachers with the less, average and high teacher effectiveness.

\section{E. Multiple Regression Analysis}

It is found that the best regression equation for predicting the overall teacher effectiveness of the primary school teachers with the 32 variables is:

$\mathrm{TE}=182.898-0.308(\mathrm{HE})-6.296(\mathrm{~A})+4.399(\mathrm{E})$

0.838 (PFC) - 0.758 (PFL) - 3.319 (EQ)

The variance explained with the help of four variables i.e. home environment, Age, Experience, Personality Factor - $\mathrm{C}$, Personality Factor $-\mathrm{L}$ and Educational Qualification is 19.50 percent.

\section{Chapterization}

Chapter - I is the introduction

Chapter - II deals with a brief review of related research works done in the field of Teaching Effectiveness in relation to Attitude towards teaching, Job Satisfaction, Job Involvement, Home Environment and Personality characteristics.

Chapter - III deals with the present study, i.e. statement of the problem, purpose of the study, scope of the study, definitions of the terms, objectives of the study, hypothesis formulated and to be tested, variables studied and limitations of the study.

Chapter - IV gives an account of methods employed in the investigation for collection of data and the techniques used in the analysis of data.

Chapter - V deals with analysis of data, results and discussion.

Chapter - VI is the summary of the study, major findings, conclusions, educational implications, recommendations and suggestions for further study.

Bibliography and Appendices are kept at the end of the thesis.

\section{References}

[1] Adval, J.D. 2010: Attitudes expressed by young people on the teaching as a career. Faculty of Educational Research, University of Mihitoba.

[2] Ajay Kumar, Mahanthy, 2006: Evaluation of Teacher Effectiveness through Students Rating, Edutracks, Vol.5, No.7. pp.8-10.

[3] Allport, G.W. 1945: Teacher Attitude and Job Satisfaction of the Married, American Educational Research Association, Stanford University, Vol.61, p.45.

[4] Allport, G.W. 1947: Teacher Attitude and Job Satisfaction of the Married, American Educational Research Association, Stanford University, Vol.61, p.45.

[5] Allport, G.W. 1961: Teacher Attitude and Academic Achievement of Married Students. American Educational Research Association, Stanford University, No. 61, p.45.

[6] Amaranth, P., Ramakrishna, V., Balan, G., and Sarasa, D. 1990: Comparative Study of the Organizational Climate of government and Privately managed higher secondary schools in Julundhar District, Journal of Education and Psychology, Punjab University, Punjab.

[7] Amar Singh, 1985: Correlates of Job Satisfaction among Different Professionals, Research in Teacher Education Abstracts, (In) Buch, M.B. (Ed.) Fourth Survey of Research of Education, (1983-88), Vol. 2, NCERT, New Delhi, 1206, p.1069.

[8] Anand, S.P. 1971: Study, of Teachers -pupil Relationship in Higher Secondary Classes in Delhi, Unpublished Ph. D. Thesis, University of Delhi, New Delhi.

[9] Anderson, L.W. 1991: Increasing Teacher Effectiveness, Paris: International Institute for Educational Planning. p.22-24.

[10] Anjana, K. 2005: A Socio-Psychological Study of Selfconcept of Dalit Students, Indian Journal of Psychological Abstracts, August, 2008, Vol. 84, No.8. pp.25-29.

[11] Annamalai, A.R. 2000: Attitude of Teachers towards Teaching, The SITU Council of Educational Research, Vol.XXVIII, 4, pp.49-71.

[12] Annammani, Chendra. 2008: School Teachers and Teaching Effectiveness, Teacher Education, Vol.7, No.1, pp.16-23.

[13] Arockia Doss, 2007: Teacher Effectiveness of College Teachers, Journal of Research Extension, Vol.3, No.11, pp.21-22.

[14] Arora, V.J. 2003: Teachers Anxiety at different Levels of Job Satisfaction, Indian Journal of Educational Review, Vol.27, No.2, pp.157-159.

[15] Arvey, R.D., Dewhise, J and Bolign, N. 1976: Job Expectations and Valences of Job Rewards for culturally disadvantaged and advantaged clerical employees, Journal of Applied Psychology, 59, 2, pp.230-232.

[16] Askew, $\mathrm{K}$ et.al., 2001: Relationship between Organizational Climate and Teaching Effectiveness of Secondary S choo. Teachers, Indian Journal of Applied Psychology, Vol.16, pp.75-81. 


\section{International Journal of Science and Research (IJSR) \\ ISSN (Online): 2319-7064}

Index Copernicus Value (2015): 78.96 | Impact Factor (2015): 6.391

[17] Aubrecht, J., Mortal, H., Anderson.K. and Apte.D. 1986: A Study of Criteria of Teaching Effectiveness, Journal of Experimental Education, Vol.34, No.1, pp.16-19.

[18] Balakrishna Reddy, P.1990: Job Satisfaction of Primary School Teachers, Unpublished M.Phil Dissertation, submitted to Sri Venkateswara University, Tirupati.

[19] Ball, K.S. 2004: Teaching Effectiveness of Primary School Teachers and its influencing factors, $\underline{M . E d}$ Dissertation, RIE, Mysore.

[20] Barr, A.S. 1952: Wisconsin studies of the measurement and prediction of Teacher Effectiveness, Journal of Experimental Education, Vol. 30, p.147.

[21] Barr, A.S., Davis, N. and Johnson, P. 1953: Research Methods. In Chester W. Harris (Eds) Encyclopaedia of Educational Research, Mc Millan Company, New York.

[22] Basappa, Narayana. 2009: Job Satisfaction - Related factors: A Study on teachers. Eductracs, Vol.13, No.2, pp.18-21.

[23] Bass, B.M. 1965: Organizational Psychology, Allygn and Bacon, Boston.

[24] Bellguard, L.K. 2006: A Socio-Psychological Study of Self-concept of Dalit Students, Indian Journal of Psychological Abstracts, August, 2005, Vol. 84, No.8. pp.25-29.

[25] Berry, J.R. 2002: Does Professional preparation make a difference, Journal of Teacher Education, Vol.13, pp.386-395.

[26] Best, J.W. 1959: Research in Education, Prentice - Hall International Inc., Englewood Cliffs. N. J.

[27] Bhandarkar, B.G. 1980: A study on Polytechnic Teachers Attitude towards Teaching Profession and its correlates, Government Polytechnic, Jalgaon, Bhopal.

[28] Birmingham, J.A, 1985: Job Satisfaction and Burnout among Minnesota Teachers, Dissertation Abstracts International, Vol. 45, No. 8, 2318-A.

[29] Blan, J. B. 1986: Predicting Job Satisfaction. From ERIC Vol, 17, No. 5. Document Reproduction Service No. ED. 210582.

[30] Blum, M.L. 1956: Industrial Psychology and its Social Foundations, Harper and Row, New York.

[31]Blum, M.L., and Naylor, J.C. 1968: Industrial Psychology and its Social Foundations, Harper and Row, New York.

[32] Blum, M.L. and Ross, J. 1942: A study of employee attitude towards various incentives, Personnel, 19, pp.438-444.

[33] Bogardus, E.W. 1941: Fundamental Social Problems, Century, New York, p.62.

[34]Boss, P. George 1965: Decisional Participation and Teacher Effectiveness, Educational Administration Quarterly, Vol. 8, No.1, pp. 44-58.

[35]Bulluck, V.J. 1952: The Relationship between Emotional Stability and Job Satisfaction and other variables of Elementary School Principals, Dissertation Abstracts International, Vol.37, No.1, 6163-A.

[36] Bush, R.C. 1942: The Assessment Resolution: New view points for Teacher Evaluation, New York State Education Department, Albany, Buffalo, New York.

[37] Carrol Bryan Shannon, 2001: Co-operating Teaching Person Students Teachers. The Center for Education, Widene University, Chester, pp 499-512.
[38] Castro, N.L.1986: Working Class Women: The relationship of Job Characteristics and Job Involvement to Psychological well-being in Employed Mothers, Dissertation Abstracts International, May' 83 , Vol.47, No.11, 3978-A.

[39] Catherine, G., Cichon, M. and Chchran, K. 1986: Job Stress in the Human Services, Beverly Hills, Sage Publications.

[40] Cattell, R.B. 1950: The Main Personality Factors in Questionnaire, Self-estimated material, Journal of Social Psychology, Vol. 31, pp. 3-38.

[41] Cattell, M.R. and Elbert, N.F. 1962: Some Personal and Organizational Determinants of Job Satisfaction of Postal Clerks, Academy of Management Journal, Vol.17, No.2, pp.368-372.

[42] Cattell, R.B. 1970: The main personality factors in questionnaire self-estimated material, Journal of Social Psychology, 31, pp.3-38.

[43] Cheek, R.C. 2006: Professional Persons in Public Organisations, Educational Administration Quarterly, Vol.8, No.3, pp.1-11.

[44] Chakrabarthy, H. 1999: A Study of Teacher Effectiveness among Graduate Teachers in Coimbatore. Journal of Educational Research and Extension, Vol.13, pp. 120-124.

[45]Chendrasekhara Reddy, K. 1980: Teaching Effectiveness and Job Satisfaction of teachers in relation to some variables, M.Ed Dissertation, S.V.University, Tirupati.

[46] Chairrisook, D.R. 1982: Five areas of teacher concern, Phi Delta Kappan, 63, 7, p.460.

[47] Cohen, G. 1977: Untrained and Trained Graduate Teachers

[48]Edward, A.L. 1949: Techniques of Attitude scale construction, Appleton Century Crofts, Inc., New York.

[49] Edward, A.L.and Kilpatrick, E.P. 1948: A technique for the construction of attitude scales, Journal of Applied Psychology, 32, pp. 374-384.

[50]Elair, N. 1984: Analyzing Teacher Behaviour, Addison Wesley Publishing Company, London.

[51]Elloy, C.J., Bhomer, M. and Kliff, N.D. 1991: The range of changing the Attitude towards Job Involvement, Journal of Applied Psychology, Vol. 28, p - 38 .

[52] English H.B. 1934: A Students dictionary of psychological terms ( $4^{\text {th }}$ Edison), Harperand Row, New York.

[53]Flangan, G. 1954: A study of the Personality Traits of Primary School Teachers in relation to their teaching effectiveness, Journal of Applied Psychology, Vol.51, No.2, pp.59-66.

[54] Farris, J.D. 1977: A study of the determinants of Job satisfaction, Dissertation Abstracts International, 37, (10), $6163-$ A.

[55]Freeman, F.S. 1968: Theory and Practice of Psychological Testing, A text book Oxford and IBH publishing House Co., New Delhi, p.37-39.

[56] Freeman, F.S. 1977: Theory and practice of psychological testing, Oxford and IBH Publishing Company, New Delhi, pp. 108-116. 


\section{International Journal of Science and Research (IJSR) \\ ISSN (Online): 2319-7064}

Index Copernicus Value (2015): 78.96 | Impact Factor (2015): 6.391

[57] Friedlander, F. 1964: Underlying Sources of Job satisfaction, Journal of Applied Psychology, 47, 4, pp.247-250

[58] Fumham, A. and Goddard, L. 1986: Sex differences in Job Satisfaction, An International Journal of Psychology, Vol.23, No.3, pp.132-146.

[59] Gangappa, M.A. 1969: The Professional Status of Teacher, Educational India, Vol.36. pp.188-190.

[60] Gannon M.J. and Hendrickson D.H. 1973: Career Orientation and Job Satisfaction among working wives, Journal of Applied Psychology, Vol.51, No.3, pp.339340.

[61] Gechman A.S. and Wierner, Y. 1975: Job Involvement and Satisfaction as related to mental health as personal fines devoted to work, Journal of Applied Psychology, 60, 4, pp.521-523.

[62] Geol, K. 1978: A study of the Personality Traits of College Teachers, Journal of Applied Psychology, Vol.50, No.1, pp. 59-60.

[63] Gilmer, B.V.H. 1966: Industrial Psychology, Mc Graw Hill Book Company, New York.

[64] Glicken, H.D. 1977: A regional study of Job Satisfaction of social workers, Dissertation Abstracts International, Vol.38, No.3, 1658-A.

[65] Godiyal, M. 1995: The impact of work involvement among the teaching professional, Journal of Indian Psychology, 7, 2, pp.34-36

[66] Godkin, R.L. 1982 : Anticipated Job Satisfaction: Attitudinal bias among University Female Business Majors, Dissertation Abstract International, Vol.43, No.1, 211-A.

[67] Good, C.V. 1945: Methodology of Educational Research, New York, pp. 104-106

[68] Good C.V. 1973: Dictionary of Education, Mc GrawHill Book Company. New Delhi.

[69] Good, Barr, A.S. and Scates.1941: Methodology of Educational Research, New York, Appleton Century Crafts, Inc., pp. 10-18.

[70] Harding. E. 1964: Characteristics of Participants in an Employee suggestion Plan, Personal Psychology, Vol. 17, pp. 289-303.

[71] Haslett, Coddet. 2010: The Administration and Teaching Satisfaction, Phi Delta Kapan, Vol. 37, pp. 258-288.

[72]Hildbrand, M. 2001: Teaching Effectiveness and Faculty Development Programmes: A Review, Journal of General Education, Vol.32. pp.140-151.

[73] Hornby, A.S , Cowie, A.P. and Lwis, J.W. 1968: Oxford Advanced Learners Dictionary of English, The English Language Book Society, OUP, London.

[74]Hornby, A.S. 1985: Oxford Advanced Learner's Dictionary of Current English, Oxford University Press, Delhi.

[75] Hunka, Poloy and Anderson, J. 2011: Job Satisfaction and Teaching Effectiveness among Minnesota Teachers, Dissertation Abstracts International, Vol. 45, No. 8, 2318-A.

[76] Huntley, J.F. 1976: Academic Evaluation and Grading: An Analysis and Some Proposals, Havard Educational Review, Vol.46, p.615.
[77] Hurdel Benjiman. 1967: Dictionary of Education, Mc Graw Hill Company, New York.

[78] Jalaja, S.S. 2004: Bureaucratism of College Teachers and their Attitude Towards Teaching Profession, M.Phil. Dissertaion, D.D.E., M.K.University, Madurai.

[79] Jalaja, R. 2009: Factors associated with teaching effectiveness among Secondary School Teachers: A Review of the Literature, Educational Research Quarterly, Vol.5, No.3, pp.8-24.

[80] Janakivalli, C. 1999: Attitude of Secondary Grade Teachers towards Teaching Profession. The Progress of Education, Vol.LXIV, No.3, October 1999.

[81] Jayamma, L. 2002: Teaching Aptitude Test, The Psycho-center, T-22, Green Park, New Delhi.

[82] Jenkins, Ronald Roy. 1990: Student Evaluation in Determining Meritorious Teachers, District Abstract International, Vol.51, No.4, pp.1064.

[83] Jerkins, Y. 1990: Education for Social, Moral and Spiritual Values, Bharatiya Shiksha Patrika, Vol.8. pp.5-6.

[84] 1992: The Job Satisfaction of School Teachers in the Republic of China as related to Personal and Organizational characteristics, Dissertation Abstracts International, Vol.38, No.6, 3167-A.

[85] Kilpatrick, J.1990: The Relationship of Job Satisfaction to perceived Staff Promotional Policies, (In) Robinson, H.A. and Canners, R.P. 1995, Job satisfaction Researches. Personal and Guidance Journal, Vol. 42, pp.136-142

[86] Kisan, M.D. 1998: The relationship between job satisfaction and attitude towards teaching in primary school teachers, Educational Journal, 3, 1, pp.16-18.

[87] Kishan, R.N. 2007: Influence of Personality on Teaching Attitude and Teaching Competency among Student-teachers, M.Phil, Dissertation, DDE, Acharya Nagarjuna University, Nagarjunanagar, Guntur.

[88] Krishnamurthy, G. 2006: A study of Home Environment on the working situations of school teachers, M.Phil. Dissertation, DDE, SVU. Tirupati.

[89]Kochhar, S.K. 1978: Educational and Vocational Guidance, Sterling Publishers, New Delhi.

[90]Koerin, B. 1975: Teaching Effectiveness and Faculty Development programme, Journal of General Education, Vol.32, No.1, pp.40-51.

[91] Lamke, T.A. 1951: Personality and Teaching Success, Journal of Experimental Education, Vol. 20, pp.217259.

[92]Lawler, and Hall, D.T. 1970: Relationship of Job Characteristics of Job Involvement, Satisfaction and Intrinsic Motivation. Journal of Applied Psychology, Vol. 54, pp.305-312.

[93] Rangarajan, V. 1999: Attitude of primary teachers towards competency based lesson plan, The SITU Council of Educational Research, Vol. XXVII, p.9.

[94]Rao, G.R.S.1970: Socio-Personal Correlates of Job Satisfaction. Indian Journal of Applied Psychology, Vol.2, pp.63-70 


\section{International Journal of Science and Research (IJSR) \\ ISSN (Online): 2319-7064}

Index Copernicus Value (2015): 78.96 | Impact Factor (2015): 6.391

\section{Appendices \\ APPENDIX - A \\ Teacher Effectiveness Scale}

(English Version)

As a teacher you might have attained some level (status) in respect of your effectiveness as a teacher. Also you might have been aspiring to attain some better level (status) in the next three years in terms of your being an effective teacher.

Please read the statement given here and indicate the step number on which you think you are now in respect of your effectiveness as a teacher and the step number you aspire to reach in the next three years. You should feel in marking your responses.

\begin{tabular}{|c|c|c|c|c|c|c|c|c|c|c|}
\hline $\mathbf{0}$ & $\mathbf{1}$ & $\mathbf{2}$ & $\mathbf{3}$ & $\mathbf{4}$ & $\mathbf{5}$ & $\mathbf{6}$ & $\mathbf{7}$ & $\mathbf{8}$ & $\mathbf{9}$ & $\mathbf{1 0}$ \\
\hline Worst & Very Poor & Some Poor & Poor & Less than Average & Average & More than Average & Good & Some Good & Very Good & Highest \\
\hline
\end{tabular}

\begin{tabular}{|c|c|c|c|}
\hline S.No. & Statement & $\begin{array}{c}\text { Step number you } \\
\text { are NOW }\end{array}$ & $\begin{array}{c}\text { Step number aspiring to attain in } \\
\text { the next THREE years }\end{array}$ \\
\hline 1. & I have full control over the subject I am teaching. & ) & ( \\
\hline 2. & I plan my lessons well in advance. & ( & ( \\
\hline 3. & I do motivate my students for learning. & ( & ) \\
\hline 4. & I possess supportive behavior. & ( & ( \\
\hline 5. & I cooperate in the work of my institution. & ( & ( \\
\hline 6. & I adjust my teaching tike judiciously. & ) & ) \\
\hline 7. & I make use of teaching-learning material to make my teaching effective. & ) & ) \\
\hline 8. & $\begin{array}{l}\text { I do exchange my experiences of subject-matter with my colleagues to become } \\
\text { more knowledgeable. }\end{array}$ & ) & ) \\
\hline 9. & \begin{tabular}{|l|} 
I am fairly creative. \\
\end{tabular} & ( & ( \\
\hline 10. & I am friendly with my colleagues. & ) & ( \\
\hline 11. & I go to classes on time and leave it on time. & ( & ( \\
\hline 12. & I resort to remedial teaching whene4ver necessary. & ( & ( \\
\hline S.No. & Statement & $\begin{array}{c}\text { Step number you } \\
\text { are NOW }\end{array}$ & $\begin{array}{c}\text { Step number aspiring to attain in } \\
\text { the next THREE years }\end{array}$ \\
\hline 13. & I have good expression. & ) & ) \\
\hline 14. & My knowledge of subject-matter is up-to-date. & ) & ) \\
\hline 15. & I invite my students for discussion outside the class hours. & ) & ( \\
\hline 16. & I value interaction of my students during teaching-learning sessions. & ) & ( \\
\hline 17. & I keep on acquiring new knowledge. & ) & ( \\
\hline 18. & I am emotionally balanced. & ) & ( \\
\hline 19. & I do not discriminated students for personal reasons. & ) & ( \\
\hline 20. & I am objective in evaluating my students. & ) & ( \\
\hline 21. & I am reasonably active. & ) & ( \\
\hline 22. & I take a great deal of interest in parent-teacher associations. & ) & ( \\
\hline 23. & $\begin{array}{l}\text { I make my teaching interesting by giving examples and situations that are } \\
\text { familiar to students. }\end{array}$ & ) & ) \\
\hline 24. & I try to stimulate the intellectual curiosity of my students during my class. & ) & ( \\
\hline 25. & I go to institution neatly dressed and smart. & ) & ) \\
\hline 26. & I do contribute in the meetings of professionals and scholarly societies. & ) & ) \\
\hline 27. & I am systematic in my presentation of lessons. & ) & ) \\
\hline 28. & I conduct tests periodically to evaluate my teaching. & ) & ( \\
\hline 29. & I have a substantial knowledge of human development and learning. & ) & ( \\
\hline 30. & I am punctual in attending my institutional work. & ) & ) \\
\hline 31. & I do possess pleasing manners. & ) & ) \\
\hline 32. & I do help my students facing personal and educational problems. & ) & ) \\
\hline 33. & $\begin{array}{l}\text { I organize the subject matter I teach to be in agreement with the course's } \\
\text { objectives. }\end{array}$ & ) & ) \\
\hline 34. & I have a fairly good memory. & ) & ) \\
\hline 35. & My gestures in the classroom are pleasant and approvable. & ( & ) \\
\hline 36. & I have a sense of duty and responsibility. & ) & ) \\
\hline 37. & $\begin{array}{l}\text { The tests I intend administering to my students will be reviewed and imported } \\
\text { upon by me. }\end{array}$ & ) & ) \\
\hline 38. & My teaching is characterized by clarity. & ) & ( \\
\hline 39. & I discuss the content of the subject matter with ease and confidence. & ) & ( \\
\hline 40. & $\begin{array}{l}\text { I have pleasant and distinct voice. } \\
\end{array}$ & ( & ( \\
\hline 41. & I value my academic achievements. & ) & ( \\
\hline
\end{tabular}

Volume 6 Issue 1, January 2017 


\section{International Journal of Science and Research (IJSR) \\ ISSN (Online): 2319-7064 \\ Index Copernicus Value (2015): 78.96 | Impact Factor (2015): 6.391}

\begin{tabular}{|c|c|c|c|c|c|}
\hline 42. & I am successfully adapt in maintain cordial human relations. & ( & ) & ( & \\
\hline 43. & I am reasonably obedient to my head of the institution. & ( & ) & ( & ) \\
\hline 44. & $\begin{array}{l}\text { I plan my lessons keeping in view the individual differences among the } \\
\text { students. }\end{array}$ & ( & ) & ( & ) \\
\hline 45. & I guide my students in completing their assignments. & ( & ) & ( & ) \\
\hline 46. & I have a great deal of interest in the subject I am teaching. & ( & ) & ( & ) \\
\hline 47. & I provide a laudable example of my personal and social living to my students. & ( & ) & ( & ) \\
\hline 48. & I show understanding and sympathy in working with my students. & ( & ) & ( & ) \\
\hline 49. & I am in the habit of summarizing the lessons, I teach, in the end. & ( & ) & ( & ) \\
\hline 50. & I encourage students to be punctual in their assignments/ records. & ( & ) & ( & ) \\
\hline 51. & $\begin{array}{l}\text { I am concerned with the maintenance of discipline in the classroom within the } \\
\text { framework of democratic atmosphere. }\end{array}$ & ( & ) & ( & ) \\
\hline 52. & I take criticisms from others as a feedback for my own self-improvement. & ( & ) & ( & ) \\
\hline 53. & I support the genuine causes of teaching community. & ( & ) & ( & ) \\
\hline 54. & Whenever necessary I do consult my colleagues in the planning of my lessons. & ( & ) & ( & ) \\
\hline 55. & I help students in their reference work. & ( & ) & ( & ) \\
\hline 56. & $\begin{array}{l}\text { I ask more thought provoking questions than fact finding questions while } \\
\text { teaching. }\end{array}$ & ( & ) & ( & ) \\
\hline 57. & I have love for my students. & ( & ) & ( & ) \\
\hline 58. & I plan my lessons based on the techniques tested and found suitable. & ( & ) & ( & ) \\
\hline 59. & I do discuss students' performance in tests with them. & ( & ) & ( & ) \\
\hline 60. & I consider my first duty to be devoted to get a good name to my institution. & ( & ) & ( & ) \\
\hline
\end{tabular}

\section{APPENDIX - B}

\section{Attitude Towards Teaching Profession Scale (English Version)}

Below are given statements pertaining to teaching profession. These statements pertaining to academic, administrative, cocurricular, socio-psychological and economic aspects. Each statement has four alternative responses against it namely Strongly Agree (SA), Agree (A), Disagree (D) and Strongly Disagree (SD). Your good self as a teacher may be having either negative or positive dispositions towards each of the statements given below in some degree. There are no right or wrong answers in your responses. Therefore, you are quite free to express your responses as you felt.

\begin{tabular}{|c|c|c|c|c|c|c|c|}
\hline S. No. & Statement & \multicolumn{6}{|c|}{ Response } \\
\hline & & SA & A & & & & \\
\hline 1. & Teaching never gets monotonous. & 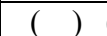 & $(\mathrm{C})$ & ( & ) & & ) \\
\hline 2. & Administrative work of the school is also one of the duties of the teacher. & ) & $(\mathrm{)})$ & ( & ) & ( & ) \\
\hline 3. & $\begin{array}{c}\text { One of the responsibilities of a teacher is to cultivate in the students an interest in the co-curricular } \\
\text { activities. }\end{array}$ & ) & ( ) & & & ( & ) \\
\hline 4. & A teacher should not sacrifice and evening of recreating in order to visit a student's home. & ) & $(\mathrm{)})$ & & & & ) \\
\hline 5. & Teachers do not determine the morals standards of a nation. & $(\quad)$ & () & ( & & ( & ) \\
\hline 6. & A teacher should not be expected to do more work than he is paid for. & ( & () & ( & ) & ( & ) \\
\hline 7. & A teacher is not expected to burden himself with problems. & ( & $($ ) & ( & ) & ( & ) \\
\hline 8. & The work of a teacher need not be supervised. & ( & $($ ) & ( & ) & ( & ) \\
\hline 9. & Teachers should encourage their sons/daughters to enter teaching profession. & ( & $($ ) & ( & & & ) \\
\hline 10. & Teaching profession offers meager monitory benefits. & () & () & ( & ) & ( & ) \\
\hline 11. & There is a scope for idling away one's time in the teaching profession. & ) & $(\mathbf{)}$ & ( & ) & ( & ) \\
\hline 12. & Teacher is an integral part of school management. & ) & $(\mathbf{)}$ & ( & ) & ( & ) \\
\hline 13. & Teachers need not be entrusted with the arrangements for excursions and matches. & ( & () & ( & ) & & ) \\
\hline 14. & Teachers should not expect students to like them. & ( & $($ ) & $\overline{0}$ & & & ) \\
\hline 15. & Teachers need not prefer their close friends to be from the teaching profession. & $(\quad)$ & $(\mathbf{)}$ & ( & & ( & ) \\
\hline 16. & Teaching develops personality and character. & ) & $(\mathbf{)}$ & ( & ) & ( & \\
\hline 17. & A teacher should be more interested in his pupils than his pay. & ) & $(\mathbf{)}$ & ( & & & ) \\
\hline 18. & Teaching makes teachers tired. & ( & () & ( & & & ) \\
\hline 19. & Teachers are to be preferred as members of school management committees. & ( & $(\mathbf{)}$ & ( & & & ) \\
\hline 20. & Teacher's participation in the co-curricular activities makes him to learn more about student's abilities. & ) & $($ ) & ( & & ( & ) \\
\hline 21. & Those who fail in other fields of work usually become teachers. & ) & () & 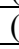 & () & ( & ) \\
\hline 22. & Teacher derive more joy and happiness in the company of children. & ) & () & ( & & & ) \\
\hline 23. & Teachers are seriously considering changing their profession. & ( & $(\mathbf{)}$ & ( & & & ) \\
\hline 24. & Teachers should not have a say in the curriculum prepared for the school. & ) & () & ( & & ( & ) \\
\hline 25. & An ideal teacher can exist only in imagination. & ) & $(\mathbf{n})$ & & & & ) \\
\hline 26. & A good teacher makes his professional life one of continuous growth. & ) & () & ( & & & ) \\
\hline 27. & Teachers should be consulted in all the administrative reforms that are proposed for the schools. & ( & $(\mathbf{)}$ & ( & () & & ) \\
\hline 28. & Inferior teachers try to cover their defects by actively participating in co-curricular activities. & ( & $(\mathbf{)}$ & ( & & & ) \\
\hline 29. & If teaching profession is not honoured, out nation will not progress. & ) & $($ ) & ( & & & ) \\
\hline 30. & There are many benefits in teaching profession other than money. & ) & $($ ) & & & & \\
\hline
\end{tabular}

Volume 6 Issue 1, January 2017 www.ijsr.net

Licensed Under Creative Commons Attribution CC BY 


\section{International Journal of Science and Research (IJSR) \\ ISSN (Online): 2319-7064}

Index Copernicus Value (2015): 78.96 | Impact Factor (2015): 6.391

\begin{tabular}{|c|c|c|c|c|c|c|c|}
\hline 31. & If a teacher had to live his life again, he should prefer to teach. & & ) & ( & & & \\
\hline 32. & Correction work is the worst part of a teacher's job. & ( & ) & ( & ) & & ) \\
\hline 33. & School administrators should not be considerate to the demands of the teachers. & ( & ) & ( & ) & 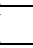 & ) \\
\hline 34. & Teachers lose their grip in teaching by participating in co-curricular activities. & ( & ) & ( & ) & 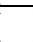 & ) \\
\hline 35. & Teaching profession has bright future. & ( & ) & ( & ) & 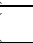 & ) \\
\hline 36. & Teachers take to teaching only because their parents wished them to do so. & ( & ) & ( & ) & & ) \\
\hline 37. & Teaching profession should not be recommended to any intelligent student. & ( & ) & ( & ) & & ) \\
\hline 38. & Teaching profession is a good medium of serving humanity. & ( & ) & ( & ) & 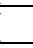 & ) \\
\hline 39. & Teachers should try to supplement their income even by overlooking professional ethics. & ( & ) & ( & ) & - & ) \\
\hline 40. & The eager faces of the students inspire teachers to do their best. & ( & ) & ( & ) & rate & ) \\
\hline 41. & It is difficult to lead a luxurious life in teaching profession. & ( & ) & ( & ) & & ) \\
\hline 42. & The community neither appreciates teacher nor recognizes their work. & ( & ) & ( & ) & -1 & ) \\
\hline 43. & A teacher can influence many generations. & ( & ) & ( & ) & 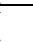 & ) \\
\hline 44. & The salaries paid to teachers are a national waste. & ( & ) & ( & ) & 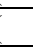 & ) \\
\hline 45. & Teaching is the best means of self-expression. & ( & ) & ( & ) & ( & ) \\
\hline 46. & Teaching is the noblest of all the professions. & ( & ) & ( & ) & ( & ) \\
\hline 47. & Men of high status do not take up teaching. & ( & ) & ( & ) & rata & ) \\
\hline 48. & Teachers do not have leadership qualities. & & ) & ( & ) & - & ) \\
\hline 49. & One should be proud of being a teacher. & ( & ) & ( & ) & ( & ) \\
\hline 50. & Teaching is an occupation requiring mediocre ability. & ( & ) & ( & ) & ( & ) \\
\hline 51. & Teaching offers a wide variety of social contacts. & ( & ) & ( & ) & ( & ) \\
\hline 52. & Teaching is one of the greatest stimulants to mental activity. & ( & ) & ( & ) & ( & ) \\
\hline 53. & Teaching profession suppresses ambitions. & & ) & ( & ) & ( & ) \\
\hline 54. & Teaching keeps one young. & ( & ) & ( & ) & ( & ) \\
\hline 55. & Teachers' contribution to national development is stupendous (extra-ordinary). & ( & ) & ( & ) & ( & ) \\
\hline
\end{tabular}

\section{Appendix - C \\ Job Satisfaction Scale \\ (English Version)}

Please read each statement carefully and state by putting a tick mark in the appropriate brackets. If you Complete Satisfaction / Some Satisfaction / Undecided / Some Dissatisfaction / Complete Dissatisfaction put a tick mark in the corresponding bracket viz., CS / SS/ U / SD / CD respectively.

\begin{tabular}{|c|c|c|c|c|c|c|}
\hline S.No & Statement & $C S$ & SS & $U$ & $S D$ & $C D$ \\
\hline 1. & I will stay overtime to finish a job even if I am not paid for it. & () & () & ( ) & () & () \\
\hline 2. & You can measure a person pretty well by how good a job he does. & ( ) & $(\mathrm{c})$ & ( ) & ( ) & ( ) \\
\hline 3. & The major job satisfaction in my life comes from my job. & () & $(\mathbf{)})$ & $(\mathbf{)}$ & $($ ) & () \\
\hline 4. & For me, morning at work really fly by. & () & $(\mathbf{)}$ & $(\mathbf{)}$ & $(\mathbf{)}$ & () \\
\hline 5. & I usually show up for work a little early to get things ready. & () & () & () & $(\mathbf{n})$ & () \\
\hline 6. & The most important thing that happen to me involve in my work. & () & $(\mathbf{)}$ & $($ ) & () & () \\
\hline 7. & Sometimes I lie awake at night thinking to me involve in my work. & () & $(\mathbf{)})$ & $($ ) & $(\mathbf{)}$ & () \\
\hline 8. & I am really a perfectionist about my work. & () & $(\mathbf{)}$ & $(\mathbf{)}$ & () & () \\
\hline 9. & I feel depressed when I fail at something connected with my job. & () & () & () & () & () \\
\hline 10. & I have other activities more important than my work. & () & $($ ) & $($ ( ) & $($ ) & $($ ) \\
\hline 11. & I live, ear and breathe my work. & () & $($ ) & $($ ) & $(\mathbf{)})$ & $($ ) \\
\hline 12. & I would probably keep working even if I did not need the money. & () & $(\mathbf{)})$ & $(\mathbf{)})$ & $(\mathbf{)}$ & $($ ( ) \\
\hline 13. & Quite often, I feel like staying house from instead of coming in. & () & $(\mathbf{)}$ & $($ ) & & $($ ) \\
\hline 14. & To me, my work is only a small part of who I am. & () & $(\mathbf{)}$ & $($ ) & $($ ) & $($ ) \\
\hline 15. & I am very much involved personally in my work. & () & $(\mathbf{n})$ & $(\mathbf{n})$ & & () \\
\hline 16. & I avoid taking on extra duties and responsibilities in my work. & () & $($ ) & $($ ) & $($ ) & ( ) \\
\hline 17. & I used to be more ambitious about my work than I am now. & () & $(\mathbf{)}$ & $(\mathbf{)}$ & $(\mathbf{)}$ & () \\
\hline 18. & Most things in life are more important than work. & () & $(\mathbf{)}$ & $(\mathbf{)}$ & $(\mathbf{n})$ & () \\
\hline 19. & I used to care more about my work, but now other things are more important to me. & () & $($ ) & $($ ) & $($ ) & ( ) \\
\hline 20. & Sometimes I would like to kick myself for the mistakes I make in my work. & () & () & () & () & ( ) \\
\hline
\end{tabular}

\section{Appendix - D \\ Job Involvement Inventory \\ (English Version)}

The following items are comments, people have made or might make about their work. Please read each statement carefully in terms of its contribution to your involvement in the job and state by putting a ' $\sqrt{ }$ ' mark in the appropriate brackets. If you Strongly Agree / Agree / Undecided / Disagree / Strongly Disagree put a ' $\sqrt{ }$ ' mark in the corresponding brackets viz., S.A / A / $\mathrm{U} / \mathrm{D} / \mathrm{SD}$. Try to avoid making the 'doubtful' category as for as possible and answer all the items. Please give your correct opinion. 


\section{International Journal of Science and Research (IJSR) ISSN (Online): 2319-7064 \\ Index Copernicus Value (2015): 78.96 | Impact Factor (2015): 6.391}

\begin{tabular}{|c|c|c|}
\hline \multirow{2}{*}{ S.No } & \multirow{2}{*}{ Statement } & Response \\
\hline & & $S A \quad A \quad U \quad D \quad S D$ \\
\hline 1. & I will stay over time to finish a job even if I am not paid for it. & $(()()()()()$ \\
\hline 2. & You can measure a person pretty well by how good a job he does. & ()()()()() \\
\hline 3. & The major satisfaction in my life comes from my job. & ()()()()() \\
\hline 4. & For me, morning at work really fly by & ()()()()() \\
\hline 5. & I usually show up for work a little early to get things ready. & ()()()()() \\
\hline 6. & The most important thing that happens to me is to involve in my work. & ()()()()() \\
\hline 7. & Sometimes, I lie awake at night thinking ahead to the next day's work. & ()()()()() \\
\hline 8. & I am really a perfectionist about my work. & ()()()()() \\
\hline 9. & I feel depressed when I fail at something connected with my work. & ()()()()() \\
\hline 10. & I have other activities more important than my work. & ()()()()() \\
\hline 11. & I live, eat and breathe my work. & ()()()() \\
\hline 12. & I would probably keep working even if I did not need the money. & ()()()()() \\
\hline 13. & Quite often I feel like staying house from instead of coming in. & ()()()()() \\
\hline 14. & To me, my work is only a small part of who I am. & ()()()()() \\
\hline 15. & I am very much involved personally in my work. & ()()()()() \\
\hline 16. & I avoid taking on extra duties and responsibilities in my work. & ()()()()() \\
\hline 17. & I used to be more ambitious about my work than I am now. & ()()()()() \\
\hline 18. & Most things in life are more important than work. & ()()()()() \\
\hline 19. & I used to care more about my work, but now other things are more important to me. & ()()()()() \\
\hline 20. & Sometimes I would like to kick myself for the mistakes I make in my work. & ()()()()() \\
\hline
\end{tabular}

Appendix - E

\section{Home Environment Inventory}

(English Version)

The following statements in this scale describe the behavior conditions that occur within home. Please indicate to what extent each of these descriptions characterize your home and indicate how often you experience this way about your home in the space after the statement.

\begin{tabular}{|c|c|c|c|c|c|}
\hline \multirow{3}{*}{ How often } & \multicolumn{5}{|c|}{ Level of Experience } \\
\cline { 2 - 6 } & Never & Rarely & Sometimes & Often & Always \\
\cline { 2 - 6 } & 1 & 2 & 3 & 4 & 5 \\
\hline
\end{tabular}

\begin{tabular}{|l|l|l|}
\hline S.No. & Statement & How often \\
\hline 1. & I live happily with my family members. & ( \\
\hline 2. & I keep elders/other members of my family informed whenever I leave home. & ( \\
\hline 3. & I feel that my family members lack the attitude of cooperation. & ( \\
\hline 4. & I feel that my family members have not yet acquired a pleasing manner. & ( \\
\hline 5. & I don't understand how to behave with my family members. & ( \\
\hline 6. & I can talk freely with the members of my family. & ( \\
\hline 7. & I feel that, no one in the family can be trusted fully. & ( \\
\hline 8. & I don't like to talk with my family members. & ) \\
\hline 9. & I feel that I am not sympathetic towards my family members. & ( \\
\hline 10. & Members of my family generally welcome my ideas and plans. & ( \\
\hline 11. & I quarrel with my family members unnecessarily. & ( \\
\hline 12. & I find it hard to get along with my family members. & ( \\
\hline 13. & I like live away from my family. & ) \\
\hline 14. & I cannot tolerate the opinion of my family members. & ( \\
\hline 15. & I get more pleasure from elsewhere that what I get in my family. & ( \\
\hline 16. & I have inferiority complex about my family own family. & ) \\
\hline 17. & I feel that my spouse do not behave upto my expectation. & ( \\
\hline 18. & I am painfully conscious that my children are not coming up to my expectations. & ( \\
\hline 19. & I meet the demands of my family members. & ( \\
\hline 20. & I have conflicts with my parents. & ( \\
\hline 21. & My parents interfere with me in every affair. & ) \\
\hline 22. & The atmosphere in my family is cheerful. & ( \\
\hline 23. & I feel hesitant to take friends to my home. & ( \\
\hline 24. & I feel that members of my family are spend thrifts. & () \\
\hline 25. & I am afraid of talking with elders of my family. & ( \\
\hline 26. & I get respect in my family. & ( \\
\hline 27. & I am happy with my children's behavior. & ) \\
\hline & & ( \\
\end{tabular}




\section{International Journal of Science and Research (IJSR)}

ISSN (Online): 2319-7064

Index Copernicus Value (2015): 78.96 | Impact Factor (2015): 6.391

What to do:

Appendix - F

16 Personality Factors Questionnaire

(English Version)

Inside this booklet there are some questions to see what attitudes and interests you have. There is no right or wrong answer; because everyone has the right to his/her own views. To be able to get the best advice from your results, you will want to answer them exactly and truly. There are three possible answers to each question. Fill in the $1^{\text {st }}$ bracket as (A) if your answer choice is the ' $a$ ' answer, in the middle bracket as (B) if your choice is the ' $b$ ' answer and in the last bracket as (C) if you choose the 'c' answer.

When you answer, keep these four points in mind:

You are asked not to spend time pondering. Give the first, natural answer as it comes to you.

Try not to fall back on the middle, 'uncertain' answers except when the answer at either end is really impossible for you.

Be sure not to skip anything, but answer every question somehow. Some may not apply to you very well, but give your best guess. Some may seem personal; but cannot be scored without a special stencil key. Answers to particular questions are not inspected.

Answer as honestly as possible what is true of you. Do not merely mark what seems "the right thing to say" to impress the examiner.

\begin{tabular}{|c|c|c|c|c|}
\hline \multirow{3}{*}{$\begin{array}{l}\text { S.No. } \\
1 .\end{array}$} & Statement & A & $\mathrm{B}$ & $\mathrm{C}$ \\
\hline & I think my memory is better than it ever was... & $(\mathbf{n})$ & () & $(\mathbf{)}$ \\
\hline & $\begin{array}{l}\text { a. Yes } \\
\text { b. in between } \\
\text { c. no }\end{array}$ & & & \\
\hline \multirow[t]{2}{*}{2.} & I could happily live alone, far from anyone, like a hermit... & $($ ) & $(\mathbf{)}$ & $(\mathbf{n})$ \\
\hline & $\begin{array}{l}\text { a. yes } \\
\text { b. occasionally } \\
\text { c. no }\end{array}$ & & & \\
\hline \multirow[t]{2}{*}{3.} & If say the sky is 'down' and winter is 'hot' I would call a criminal. & $(\mathbf{)}$ & $(\mathbf{n}$ & $($ ) \\
\hline & $\begin{array}{l}\text { a. a gangster } \\
\text { b. a saint } \\
\text { c. a cloud }\end{array}$ & & & \\
\hline \multirow[t]{2}{*}{4.} & When going to bed I : & $($ ) & $(\mathbf{)}$ & $(\mathbf{n})$ \\
\hline & $\begin{array}{l}\text { a. drop off to sleep quickly } \\
\text { b. in between } \\
\text { c. have difficulty falling asleep }\end{array}$ & & & \\
\hline \multirow[t]{2}{*}{5.} & When driving a car in a line of traffic, I feel satisfied: & $($ ) & $(\mathbf{n}$ & $($ ) \\
\hline & $\begin{array}{l}\text { a. to remain behind most of the other cars } \\
\text { b. in between } \\
\text { c. Only after I have reached the front of the line }\end{array}$ & & & \\
\hline \multirow[t]{2}{*}{6.} & At a party I let others keeps the jokes and stories going & $(\mathbf{n})$ & $(\mathbf{n}$ & $(\mathbf{n})$ \\
\hline & $\begin{array}{l}\text { a. yes } \\
\text { b. sometimes } \\
\text { c. no }\end{array}$ & & & \\
\hline \multirow[t]{2}{*}{7.} & It is important to me not to live in messy surroundings & $(\mathbf{n})$ & $(\mathbf{n}$ & $(\mathbf{)}$ \\
\hline & $\begin{array}{l}\text { a. true } \\
\text { b. uncertain } \\
\text { c. false }\end{array}$ & & & \\
\hline \multirow[t]{2}{*}{8.} & Most people I meet at a party are undoubtedly glad to see me... & ( ) & $(\mathbf{n}$ & $($ ) \\
\hline & $\begin{array}{l}\text { a. yes } \\
\text { b. sometimes } \\
\text { c. no }\end{array}$ & & & \\
\hline \multirow[t]{2}{*}{9.} & I would rather exercise by & $(\mathbf{)}$ & $(\mathbf{n}$ & $(\mathbf{n})$ \\
\hline & $\begin{array}{l}\text { a. fencing and dancing } \\
\text { b. in between } \\
\text { c. wresting and baseball }\end{array}$ & & & \\
\hline \multirow[t]{2}{*}{10.} & I smile to myself at the big difference between what people do and what they say and they do & $(\mathbf{n})$ & $(\mathbf{n}$ & $(\mathbf{n})$ \\
\hline & $\begin{array}{l}\text { a. yes } \\
\text { b. occasionally } \\
\text { c. no }\end{array}$ & & & \\
\hline \multirow[t]{2}{*}{11.} & In reading about an accident I like to find out exactly how it happened. & $(\mathbf{n})$ & $($ ) & $($ ) \\
\hline & $\begin{array}{l}\text { a. always } \\
\text { b. sometimes } \\
\text { c. seldom }\end{array}$ & & & \\
\hline
\end{tabular}

Volume 6 Issue 1, January 2017

www.ijsr.net

Licensed Under Creative Commons Attribution CC BY 


\section{International Journal of Science and Research (IJSR)}

ISSN (Online): 2319-7064

Index Copernicus Value (2015): 78.96 | Impact Factor (2015): 6.391

\begin{tabular}{|l|l}
\hline 12. & When friends play a joke on me, I usually enjoy it as others, without feeling at all upset
\end{tabular}
a. true
b. in between
c. false

13. When someone speaks angrily to me, I can forget the matter quickly

a. true

b. uncertain

c. false

14. I like to 'dream up' new ways of doing things rather than to be a practical follower of well- tried ways

true

Uncertain

false

15. $\quad$ When I plan something, I like to do so quite alone without any outside help
a. yes
b. occasionally
c. no

16. I consider myself less 'high strung' than most people

a. true

b. in between

c. false.

17. I get impatient easily with people who do not decide quickly

a. true

b. in between

c. false.

18. I have sometimes; even if briefly, had hateful feelings towards my parents

a. Yes

b. in between

c. No

19. I would rather tell my inner most thoughts to

a. my friends

b. un certain

c. write in dairy

$20 . \quad$ I think the opposite of the opposite of 'in exact' is
a. general
b. exact
c. approximate

21. $\quad$ I always have lots of energy at it times when I need it

yes

b. in between

c. no

22. I am more annoyed by a person who:

a. tells off-colour jokes and embarrasses people.

b. uncertain

c. is late for an appointment and inconveniences me.

23. I greatly enjoy inviting guests and amusing them

a. true

b. uncertain

c. false

$24 . \quad$ I feel that:

a. some jobs just don't have to be done so carefully as others

b. in between

c. any job should be done thoroughly if you do it at all.

25. I have always had to fight against being too shy.

a. yes

b. in between

c. no

$26 . \quad$ It would be more interesting to be:

a. a priest

b. uncertain

c. a colonel

27. If a neighbour cheats me in small things I would rather humour him at than show him up:

a. yes

b. uncertain

c. no

28. I like a friend who:

a. is efficient and practical in his interests

b. in between

c. seriously thinks out his attitudes towards life.

Volume 6 Issue 1, January 2017

www.ijsr.net

Licensed Under Creative Commons Attribution CC BY 


\section{International Journal of Science and Research (IJSR) \\ ISSN (Online): 2319-7064 \\ Index Copernicus Value (2015): 78.96 | Impact Factor (2015): 6.391}

$29 . \quad$ It bothers me if I hear others expressing ideas that are contrary to those that I firmly believe:
a. true
b. in between
c. no

30. I am over-conscientious, worrying over my past acts of mistakes:

a. true

b. in between

c. no

31. If I were good at both, I would rather:

a. playing chess

b. in between

c. go bowling

32. $\quad$ I like to join with people who show lively group enthusiasm:

a. yes

b. sometimes

c. no

33. I put more faith in :
a. insurance
b. in between
c. good fortune

34. I am forget my worries and responsibilities whenever I need to:

a. yes

b. sometime

c. no

35. It's hard for me to admit it when I am worrying:
a. yes
b. sometime
c. no

36. $\quad$ In a factory it would be more interesting to be in charge of :

Machinery or keeping records

In between

Talking to and hiring new people

37. Which word does not belong with the other two:
a. cat
b. near
c. Sun

38. $\quad$ Minor distractions seem:

a. to irritate me

b. in between

c. not to bother me at all

39. I am quite happy to be waited on at appropriate times, by personal servants:
a. often
b. sometimes

c. never

40. $\quad$ I would rather live in a town:

artistically laid out, but relatively poor

uncertain

that is rough, prosperous and booming

41. People should insist more than they:
b. sometimes

c. no

42. I have been told that, as a child, I was rather:

a. quite and kept myself

b. in between

c. lively and always active

43. I enjoy routine, constructive work, using a good piece of machinery or apparatus:
a. yes
b. in between
c. no

\begin{tabular}{l|l}
\hline 44. & I think most witnesses tell the truth even if it becomes embarrassing:
\end{tabular}

a. yes

b. in between

c. no

45. $\quad$ When I meet a new person I would rather :

a. discuss his politics and social views

b. in between

c. have him tell me some good new jokes.

Volume 6 Issue 1, January 2017 


\section{International Journal of Science and Research (IJSR) \\ ISSN (Online): 2319-7064}

Index Copernicus Value (2015): 78.96 | Impact Factor (2015): 6.391

\begin{tabular}{|c|c|c|c|c|}
\hline 46. & I try to make my laughter at jokes quitter than most people's : & $(\mathbf{n})$ & () & $(\mathbf{)}$ \\
\hline & $\begin{array}{l}\text { a. yes } \\
\text { b. in between } \\
\text { c. no }\end{array}$ & & & \\
\hline 47. & I never feel so wretched that I want to cry: & $($ ) & ( ) & () \\
\hline & $\begin{array}{l}\text { a. true } \\
\text { b. uncertain } \\
\text { c. false }\end{array}$ & & & \\
\hline 48. & In music I enjoy: & $($ ) & $($ ) & $($ ) \\
\hline & $\begin{array}{l}\text { a. military band marches } \\
\text { b. uncertain } \\
\text { c. violin solos }\end{array}$ & & & \\
\hline 49. & I would rather spend two weeks in the summer: & $(\quad)$ & $(\quad)$ & $(\mathbf{)}$ \\
\hline & $\begin{array}{l}\text { a. bird watching and walking in the country } \\
\text { b. un certain } \\
\text { c. being a leader of a group in a camp }\end{array}$ & & & \\
\hline 50. & The effort taken in planning ahead: & $($ ) & $(\mathbf{n}$ & () \\
\hline & $\begin{array}{l}\text { a. is never wasted } \\
\text { b. in between } \\
\text { c. is not worth it. }\end{array}$ & & & \\
\hline 51. & In considerate acts or remarks by my neighbours do not make me touchy and unhappy: & $(\mathbf{n}$ & () & () \\
\hline & $\begin{array}{l}\text { a. true } \\
\text { b. uncertain } \\
\text { c. false }\end{array}$ & & & \\
\hline 52. & When I know I'm doing the right thing, I find my ways task easy: & $(\mathbf{)}$ & $(\quad)$ & $(\mathbf{)}$ \\
\hline & $\begin{array}{l}\text { a. always } \\
\text { b. sometimes } \\
\text { c. seldom }\end{array}$ & & & \\
\hline 53. & I would rather be: & $($ ) & $(\quad)$ & () \\
\hline & $\begin{array}{l}\text { a. in business office organizing and seeing people } \\
\text { b. in between } \\
\text { c. an architect, drawing plans in a quiet room } \\
\end{array}$ & & & \\
\hline 54. & "House" is to "room" as "tree" is to: & $($ ) & $($ ) & $($ ) \\
\hline & $\begin{array}{l}\text { a. forest } \\
\text { b. plant } \\
\text { c. leaf }\end{array}$ & & & \\
\hline 55. & Things go wrong for me: & $($ ) & $($ ) & $($ ) \\
\hline & $\begin{array}{l}\text { a. rarely } \\
\text { b. occasionally } \\
\text { c. frequently } \\
\end{array}$ & & & \\
\hline 56. & In most things in life, I believe in: & $(\quad)$ & () & () \\
\hline & $\begin{array}{l}\text { a. taking a gamble } \\
\text { b. in between } \\
\text { c. playing it safe }\end{array}$ & & & \\
\hline 57. & Some people may think I talk too much: & $(\quad)$ & () & () \\
\hline & $\begin{array}{l}\text { a. likely } \\
\text { b. uncertain } \\
\text { c. unlikely }\end{array}$ & & & \\
\hline 58. & I admire more: & $(\quad)$ & () & $(\mathbf{)}$ \\
\hline & $\begin{array}{l}\text { a. a clever, but undependable man } \\
\text { b. in between } \\
\text { c. a man who is average, but strong to resist temptations }\end{array}$ & & & \\
\hline 59. & I make decisions: & $($ ) & () & $($ ) \\
\hline & $\begin{array}{l}\text { a. faster than many people } \\
\text { b. uncertain } \\
\text { c. slower than most people }\end{array}$ & & & \\
\hline 60. & I am more impresses by: & $(\mathbf{n}$ & $(\mathbf{)}$ & $($ ) \\
\hline & $\begin{array}{l}\text { a. acts of skill and grace } \\
\text { b. in between } \\
\text { c. acts of strength and power }\end{array}$ & & & \\
\hline 61. & I am considered a co-operative person: & $(\quad)$ & () & () \\
\hline & $\begin{array}{l}\text { a. yes } \\
\text { b. in between } \\
\text { c. no }\end{array}$ & & & \\
\hline 62. & I enjoy talking more with polished, sophisticated people than without spoken, down to earth individuals: & $(\mathbf{n}$ & $(\mathbf{n}$ & $(\mathbf{)}$ \\
\hline & $\begin{array}{l}\text { a. yes } \\
\text { b. in between } \\
\text { c. no }\end{array}$ & & & \\
\hline
\end{tabular}

Volume 6 Issue 1, January 2017 www.ijsr.net

Licensed Under Creative Commons Attribution CC BY 
63. $\quad$ I prefer:

a. keep my problems to myself

b. in between

c. talk about them to my friends

64. If a person doesn't answer when I make a suggestion, I feel I have said something silly:

a. true

b. in between

c. false

65. I learned more in my school days by:

a. going to classes

b. in between

c. reading books

\begin{tabular}{l|l}
66. & I avoid getting involved in social responsibilities and organizations:
\end{tabular}

a. true

b. sometimes

c. false

67. When a problem gets hard and others is a lot to do, I try:

a different problems

b. in between

c. a different attack on the same problem

68. $\quad$ I get strong emotional mood-anxiety, anger laugher etc. that seems to arise without much actual cause:

a. yes

b. occasionally

c. no

69. My mind doesn't work so clearly at sometimes as it does at others:
a. true
b. in between

c. false

70. $\quad$ I am happy to oblige people by making appointments at times they prefer, even if it is a bit inconvenient to me:

a. yes

b. sometimes

c. no

\begin{tabular}{l|l}
\hline 71. & I think the proper number to continue the series: $1,2,3,6,5$ is :
\end{tabular}
a. 10
b. 5
c. 7

72. I have occasionally had a brief tough of faintness, dizziness or light headedness for no apparent reason:

a. yes

b. uncertain

c. no

73. I would rather do without something than put a waiter or waitress to a lot of extra trouble:
a. yes
b. occasionally
c. no

\begin{tabular}{l|l}
\hline 74. & I live for the 'here and now' more than most people do:
\end{tabular}

a. true

b. un certain

c. no

75. In a party, I like:

a. to get into worthwhile conversation

b. in between

c. to see people relax and completely let go

\begin{tabular}{lll}
\hline 76. & I speak my mind no matter how many people are around:
\end{tabular}

a. yes

b. sometimes

c. no

77. $\quad$ I could go back in time, I could rather meet:

a. Columbus

b. uncertain

c. Shakespeare

78. I have to stop myself from getting too involved in trying to straighten out other people's problems:

a. yes

b. sometimes

c. no

79. $\quad$ In a store market, I would prefer to:

a. design and do window displays

b. uncertain

c. be a cashier

80. $\quad$ If people think poorly of me, I can still go no calmly in my own mind:

Volume 6 Issue 1, January 2017 


\begin{tabular}{|c|c|c|c|c|}
\hline & $\begin{array}{l}\text { a. yes } \\
\text { b. in between } \\
\text { c. no }\end{array}$ & & & \\
\hline \multirow[t]{2}{*}{81.} & If an old friend seems cold and reserved to me, I usually: & $(\mathrm{)})$ & $($ ) & $($ ) \\
\hline & $\begin{array}{l}\text { just think "He is in bad mood" } \\
\text { uncertain } \\
\text { c. worrying about what I may have done wrong } \\
\end{array}$ & & & \\
\hline \multirow[t]{2}{*}{82.} & More trouble arises from people: & $(\mathbf{)}$ & $($ ) & $($ ( ) \\
\hline & $\begin{array}{l}\text { a. changing and meddling with ways that are already satisfactory } \\
\text { b. uncertain } \\
\text { c. turning down new, promising methods. }\end{array}$ & & & \\
\hline \multirow[t]{2}{*}{83.} & I greatly enjoy talking to people about local problems: & $(\mathbf{n}$ & () & $(\mathbf{)}$ \\
\hline & $\begin{array}{l}\text { a. yes } \\
\text { b. sometimes } \\
\text { c. no }\end{array}$ & & & \\
\hline \multirow[t]{2}{*}{84.} & Prim, strict people don't seem to get along well with me: & $(\quad)$ & $(\quad)$ & $(\mathbf{)}$ \\
\hline & $\begin{array}{l}\text { a. true } \\
\text { b. sometimes } \\
\text { c. false }\end{array}$ & & & \\
\hline \multirow[t]{2}{*}{85.} & I guess I'm less irritable than most people: & $(\mathbf{n}$ & $(\quad)$ & $(\mathbf{)}$ \\
\hline & $\begin{array}{l}\text { a. true } \\
\text { b. uncertain } \\
\text { c. false }\end{array}$ & & & \\
\hline \multirow[t]{2}{*}{86.} & I may be less considerate of other people than they are of me: & $($ ) & $($ ) & $($ ) \\
\hline & $\begin{array}{l}\text { a. true } \\
\text { b. sometimes } \\
\text { c. false }\end{array}$ & & & \\
\hline \multirow[t]{2}{*}{87.} & $\begin{array}{l}\text { I would just as soon let someone else have all the worry of being in charge of an organization of which I am a } \\
\text { member: }\end{array}$ & $(\mathbf{)}$ & ( ) & ( ) \\
\hline & $\begin{array}{l}\text { a. true } \\
\text { b. uncertain } \\
\text { c. false }\end{array}$ & & & \\
\hline \multirow[t]{2}{*}{88.} & $\begin{array}{l}\text { If the two hands on a watch come together exactly every } 65 \text { minutes (according to an accurate watch), the watch is } \\
\text { running: }\end{array}$ & ( ) & ( ) & ( ) \\
\hline & $\begin{array}{l}\text { a. slow } \\
\text { b. on time } \\
\text { c. fast }\end{array}$ & & & \\
\hline \multirow[t]{2}{*}{89.} & I am bored: & $(\mathbf{n}$ & $(\mathbf{n}$ & $(\mathbf{)}$ \\
\hline & $\begin{array}{l}\text { a. often } \\
\text { b. occasionally } \\
\text { c. seldom }\end{array}$ & & & \\
\hline \multirow[t]{2}{*}{90.} & People say that I like to have things done my own way: & $(\quad)$ & () & $(\mathbf{)}$ \\
\hline & $\begin{array}{l}\text { a. yes } \\
\text { b. occasionally } \\
\text { c. no }\end{array}$ & & & \\
\hline \multirow[t]{2}{*}{91.} & I find it wise to avoid too much excitement because it tends to wear me out: & $($ ) & $($ ) & $($ ( ) \\
\hline & $\begin{array}{l}\text { a. yes } \\
\text { b. occasionally } \\
\text { c. no }\end{array}$ & & & \\
\hline \multirow[t]{2}{*}{92.} & At home, with a bit of spare time, I: & $($ ) & () & () \\
\hline & $\begin{array}{l}\text { a. use it chatting and relaxing } \\
\text { b. in between } \\
\text { c. arrange to fill it with special jobs. }\end{array}$ & & & \\
\hline \multirow[t]{2}{*}{93.} & I am shy and careful about making friendships with new people: & $(\mathbf{n}$ & $(\mathbf{n}$ & $(\mathbf{n})$ \\
\hline & $\begin{array}{l}\text { a. yes } \\
\text { b. occasionally } \\
\text { c. no }\end{array}$ & & & \\
\hline \multirow[t]{2}{*}{94.} & I think that what people say in poetry could be put just as exactly in plain prose: & $(\mathbf{n}$ & () & $(\mathbf{n})$ \\
\hline & $\begin{array}{l}\text { a. yes } \\
\text { b. sometimes } \\
\text { c. no }\end{array}$ & & & \\
\hline \multirow[t]{2}{*}{95.} & I suspect that people who act friendly to me can be disloyal behaving my back: & ()$^{2}$ & $(\mathbf{n}$ & () \\
\hline & $\begin{array}{l}\text { a. yes, generally } \\
\text { b. occasionally } \\
\text { c. no, rarely }\end{array}$ & & & \\
\hline \multirow[t]{2}{*}{96.} & I think that even the most dramatic experiences during the year leave my personality much the same as it was: & $($ ( ) & $($ ) & $($ ( ) \\
\hline & $\begin{array}{l}\text { a. yes } \\
\text { b. sometimes }\end{array}$ & & & \\
\hline
\end{tabular}

Volume 6 Issue 1, January 2017 
International Journal of Science and Research (IJSR)

ISSN (Online): 2319-7064

Index Copernicus Value (2015): 78.96 | Impact Factor (2015): 6.391

\begin{tabular}{|c|c|c|c|c|}
\hline & c. no & & & \\
\hline \multirow[t]{2}{*}{97.} & It would seem more interesting to be a : & ()$^{\prime}$ & $(\mathbf{n}$ & () \\
\hline & $\begin{array}{l}\text { a. naturalist and work with plants } \\
\text { b. uncertain } \\
\text { c. public accountant or insurance man }\end{array}$ & & & \\
\hline \multirow[t]{2}{*}{98.} & I get un reasonable fears or distastes for something, for example, particular animals, plants and so on: & $(\mathbf{n}$ & () & () \\
\hline & $\begin{array}{l}\text { a. yes } \\
\text { b. sometimes } \\
\text { c. no }\end{array}$ & & & \\
\hline \multirow[t]{2}{*}{99.} & I like to think out always in which our world could be changed to improve it: & ()$^{\prime}$ & $(\mathbf{n}$ & () \\
\hline & $\begin{array}{l}\text { a. yes } \\
\text { b. occasionally } \\
\text { c. no }\end{array}$ & & & \\
\hline \multirow[t]{2}{*}{100.} & I prefer games where: & $($ ) & () & $(\quad)$ \\
\hline & $\begin{array}{l}\text { a. You're on a team or have a partner } \\
\text { b. uncertain } \\
\text { c. each person is on his own }\end{array}$ & & & \\
\hline \multirow[t]{2}{*}{101.} & At night I have rather fantastic or ridiculous dreams: & $(\mathbf{n}$ & () & () \\
\hline & $\begin{array}{l}\text { a. yes } \\
\text { b. occasionally } \\
\text { c. no }\end{array}$ & & & \\
\hline \multirow[t]{2}{*}{102.} & If left in a lovely house I tend, after a time to feel a bit anxious or fearful: & ( ) & () & () \\
\hline & $\begin{array}{l}\text { a. yes } \\
\text { b. sometimes } \\
\text { c. no }\end{array}$ & & & \\
\hline \multirow[t]{2}{*}{103.} & I may deceive people by being friendly when I really dislike them: & ()$^{\prime}$ & () & () \\
\hline & $\begin{array}{l}\text { a. yes } \\
\text { b. sometimes } \\
\text { c. no }\end{array}$ & & & \\
\hline \multirow[t]{2}{*}{104.} & Which word does not belong to the other two: & $(\mathbf{n}$ & () & () \\
\hline & $\begin{array}{l}\text { a. think } \\
\text { b. see } \\
\text { c. hear }\end{array}$ & & & \\
\hline \multirow[t]{2}{*}{105.} & If Mary's mother is Fred's father's sister. What relation is Fred to Mary's father: & ()$^{\prime}$ & $(\mathbf{n}$ & () \\
\hline & $\begin{array}{l}\text { a. } \text { cousin } \\
\text { b. nephew } \\
\text { c. uncle }\end{array}$ & & & \\
\hline
\end{tabular}

Appendix - G

Personal Data Sheet

\begin{tabular}{|c|c|c|}
\hline 1. & Name of the Teacher & Men / Women \\
\hline 2. & Name of the school \& Address & years \\
\hline 3. & Gender & years \\
\hline 4. & Age & Government / Municipality / Private \\
\hline 5. & Experience & Primary / Upper primary \\
\hline 6. & Locality & SC / ST / BC / OC \\
\hline 7. & Qunagement of the school & Hindu / Muslim / Christian \\
\hline 8. & Type of School & Joint Family / Nuclear Family \\
\hline 9. & Caste & \\
\hline 10. & Religion & \\
\hline 11. & Type of family & \\
\hline 13. & Total number of family members & \\
\hline
\end{tabular}

Volume 6 Issue 1, January 2017 